\title{
ANALISIS ALTERNATIF PERENCANAAN DIMENSI TEROWONGAN PENGELAK BENDUNGAN SIDAN
}

\author{
A. A. Ngr. Billy Narendra' ${ }^{1)}$, Cok Agung Yujana ${ }^{1)}$, I Ketut Yasa Bagiarta ${ }^{1)}$, dan \\ Putu Aryastana ${ }^{1)}$ \\ 1) Program Studi Teknik Sipil, Universitas Warmadewa, Denpasar, Bali \\ billynarendra07@gmail.com
}

\begin{abstract}
The deficit of water supply in Bali Province has led to plans to build the Sidan Dam. The dam is designed with an upright core and is equipped with a diversion tunnel that serves to divert the flow of the river during the construction of the dam and control excess water. The diversion tunnel at Sidan Dam was originally designed with a horseshoe shape. The objective of this study is to design the alternative dimensions of the Sidan Dam diversion tunnel with a circular cross-section. The results of the analysis found that the diameter of the diversion tunnel was $5 \mathrm{~m}$, with a 25-year return design discharge of 265.54 $\mathrm{m}^{3} / \mathrm{sec}$. The thickness of the tunnel walls is designed to be $0.5 \mathrm{~m}$ thick with materials made of reinforced concrete, where the main reinforcement used 3D25-500 and the divider reinforcement used D25-500.
\end{abstract}

Keywords: alternative, dam, dimension, diversion tunnel, Sidan

\begin{abstract}
ABSTRAK
Kekurangan pasokan air di Provinsi Bali menyebabkan adanya rencana pembangunan Bendungan Sidan. Bendungan ini direncanakan dengan inti tegak dan dilengkapi dengan terowongan pengelak yang berfungsi membelokkan aliran sungai pada saat konstruksi bendungan dan mengontrol air yang berlebih. Terowongan pengelak di Bedungan Sidan awalnya dirancang dengan bentuk tapal kuda. Tujuan dari perencanaan ini adalah untuk merencakan dimensi alternatif terowongan pengelak Bedungan Sidan dengan penampang berbentuk lingkaran. Hasil analisis mendapatkan diameter terowongan pengelak adalah $5 \mathrm{~m}$, dengan debit rancangan kala ulang 25 tahun sebesar $265.54 \mathrm{~m}^{3} / d t$. Tebal dinding terowongan direncanakan setebal $0.5 \mathrm{~m}$ dengan bahan terbuat dari beton bertulang, dimana pada tulangan utama digunakan 3D25-500 dan pada tulangan bagi digunakan D25-500.
\end{abstract}

Kata kunci: alternatif, bendungan, dimensi, terowongan pengelak, Sidan 


\section{PENDAHULUAN}

Pertumbuhan kegiatan ekonomi dan peningkatan jumlah penduduk sangat berpengaruh terhadap meningkatnya kebutuhan air, namun pada saat yang bersamaan terjadi penurunan ketersediaan air akibat adanya perubahan iklim global (Biemans et al., 2011; Darmayasa, Aryastana, \& Rahadiani, 2018). Sebagai salah satu provinsi di Indonesia, Bali juga memiliki permasalahan peningkatan jumlah kebutuhan air dan menurunnya kertersediaan air akibat pengaruh perubahan iklim (Aryastana, Rahadiani, \& Adnyana, 2019). Ketersediaan air di Provinsi Bali hanya sebesar $101 \mathrm{~m}^{3} /$ detik, sedangkan kebutuhan airnya mencapai 216 $\mathrm{m}^{3} /$ detik (Anonim, 2019a). Kementerian Pekerjaan Umum dan Perumahan Rakyat melalui Balai Wilayah Sungai Bali-Penida memiliki program membangun dua Bendungan yaitu Bendungan Sidan dan Tamblang dalam upaya memenuhi kekerangan persediaan air. Pembangunan Bendungan Tamblang bertujuan untuk mencukupi keperluan air di Bali Utara, sedangkan Bendungan Sidan untuk mencukupi kebutuhan air di Kabupaten Tabanan, Badung dan Denpasar.

Bendungan Sidan terletak pada Daerah Aliran Sungai (DAS) Ayung, dimana daerah genang dan as bendungan membentang pada tiga kabupaten yaitu Kabupaten Badung, Kabupaten Gianyar, dan Kabupaten Bangli. Bendungan Sidan memiliki fungsi sebagai penampung air dan pembangkit listrik tenaga air. Bendungan ini direncanakan dengan inti tegak dan dilengkapi dengan terowongan pengelak yang berfungsi membelokkan aliran sungai pada saat konstruksi bendungan dan mengontrol air yang berlebih (Rofikha, Marsudi, \& Cahya, 2019; Simatupang, Tanan, \& Lukman, 2020).

Terowongan pengelak di Bedungan Sidan dirancang dengan bentuk tapal kuda. Tujuan dari perencanaan ini adalah untuk merencakan dimensi alternatif terowongan pengelak Bedungan Sidan dengan penampang berbentuk lingkaran.

\section{KAJIAN PUSTAKA}

\subsection{Kajian Hidrologi}

Kajian permulaan dalam perencanaan penampang bangunan keairan adalah analisis hidrologi (Simatupang, Tanan, \& Lukman, 2020). Penentuan debit banjir rencana merupakan bagian dari analisis hidrologi. Debit banjir rencana membutuhkan data curah hujan sebagai data inputnya. Perencanaan debit banjir memerlukan perhitungan curah hujan ratarata dalam suatu kawasan (Sosrodarsono \& 
Takeda, 1977). Metode Isohyet, polygon Thiessen, dan rata-rata artimetik merupakan pendekatan yang digunakan dalam analisis rata-rata curah hujan di kawasan DAS (Loebis, 1987). Komponen perhitungan lain dalam kajian debit banjir rancangan adalah (Soemarto, 1987; Triatmodjo, 2008):

1. Perhitungan curah hujan maksimum tahunan.

2. Analisis distribusi frekuensi dengan metode Log Person III, Gumber, dan Normal.
3. Menghitung curah hujan efektif.

4. Menghitung curah hujan rancangan.

5. Analisis hidrograf banjir dengan mengunakan hidrograf satuan Nakayasu.

\subsection{Hidrolika Saluran}

Tabel 1 menunjukan hubungan tinggi kecepatan dan debit pada kedalaman kritis dan tekanan statis dalam saluran penampang lingkaran, sedangkan pada Tabel 2 adalah untuk aliran seragam.

Tabel 1. Tinggi Kecepatan dan Debit pada Kedalaman Kritis dan Tekanan Statis dalam Saluran Penampang Lingkaran

\begin{tabular}{|c|c|c|c|c|c|c|c|c|c|c|c|}
\hline$\frac{d}{D}$ & $\frac{h_{c}}{D}$ & $\frac{Q_{c}}{D^{2}}$ & $\frac{P}{D^{3}}$ & $\frac{d}{D}$ & $\frac{h_{c}}{D}$ & $\frac{Q_{c}}{D^{2}}$ & $\frac{P}{D^{3}}$ & $\frac{d}{D}$ & $\frac{h_{c}}{D}$ & $\frac{Q_{c}}{D^{2}}$ & $\frac{P}{D^{3}}$ \\
\hline 1 & 2 & 3 & 4 & 1 & 2 & 3 & 4 & 1 & 2 & 3 & 4 \\
\hline 0.01 & 0.0033 & 0.0006 & 0.0000 & 0.34 & 0.1243 & 0.6657 & 0.0332 & 0.67 & 0.2974 & 2.4464 & 0.1644 \\
\hline .02 & .0067 & .0025 & .0000 & .35 & .1281 & .7040 & .0356 & .68 & .3045 & 2.5182 & .1700 \\
\hline .03 & .0101 & .0055 & .0001 & .36 & .1326 & .7433 & .0381 & .69 & .3125 & 2.5912 & .1758 \\
\hline .04 & .0134 & .0096 & .0002 & .37 & .1368 & .7836 & .0407 & .70 & .3204 & 2.6656 & .1816 \\
\hline .05 & .0165 & .0153 & .0003 & .38 & .1411 & .8249 & .0434 & .71 & .3286 & 2.7414 & .1875 \\
\hline .06 & .0203 & .0220 & .0005 & .39 & .1454 & .8671 & .0462 & .72 & .3371 & 2.8188 & .1935 \\
\hline .07 & .0237 & .0298 & .0007 & .40 & .1497 & .9103 & .0491 & .73 & .3459 & 2.8977 & .1996 \\
\hline .08 & .0271 & .0389 & .0010 & .41 & .1541 & .9345 & .0520 & .74 & .3552 & 2.9783 & .2058 \\
\hline .09 & .0306 & .0491 & .0013 & .42 & .1586 & .9996 & .0551 & .75 & .3646 & 3.0607 & .2121 \\
\hline .10 & .0341 & .0605 & .0017 & .43 & .1631 & 1.0458 & .0583 & .76 & .3749 & 3.1450 & .2185 \\
\hline .11 & .0376 & .0731 & .0021 & .44 & .1676 & 1.0929 & .0616 & .77 & .3355 & 3.2314 & .2249 \\
\hline .12 & .0411 & .0868 & .0026 & .45 & .1723 & 1.1410 & .0650 & .78 & .3967 & 3.3200 & .2314 \\
\hline .13 & .0446 & .1016 & .0032 & .46 & .1769 & 1.1899 & .0681 & .79 & .4035 & 3.4112 & .2380 \\
\hline .14 & .0482 &. .1176 & .0036 & .47 & .1817 & 1.2399 & .0720 & .80 & .4210 & 3.5050 & .2447 \\
\hline .15 & .0517 & .1347 & .0045 & .48 & .1885 & 1.2908 & .0757 & .81 & .4343 & 3.6019 & .2515 \\
\hline .16 & .0553 & .1530 & .0053 & .49 & .1914 & 1.3427 & .0795 & .82 & .4485 & 3.7021 & .2584 \\
\hline .17 & .0589 & .1724 & .0061 & .50 & .1961 & 1.3955 & .0833 & .83 & .4638 & 3.5061 & .2653 \\
\hline .18 & .0626 & .1928 & .0070 & .51 & .2014 & 1.4493 & .0873 & .84 & .4503 & 3.9144 & .2723 \\
\hline .19 & .0662 & .2144 & .0080 & .52 & .2065 & 1.5041 & .0911 & .85 & .4982 & 4.0276 & .2794 \\
\hline .20 & .0699 & .2371 & .0091 & .53 & .2117 & 1.5596 & .0954 & .86 & .5177 & 4.1465 & .2865 \\
\hline .21 & .0736 & .2609 & .0103 & .54 & .2170 & 1.6164 & .0998 & .87 & .5392 & 4.2721 & .2936 \\
\hline .22 & .0773 & .2857 & .0115 & .55 & .2224 & 1.6735 & .1042 & .88 & .5632 & 4.4056 & .3011 \\
\hline .23 & .0811 & .3116 & .0128 & .56 & .2279 & 1.7327 & .1087 & .89 & .5900 & 4.5480 & .3054 \\
\hline .24 & .0846 & .3366 & .0143 & .57 & .2335 & 1.7923 & .1133 & .90 & .6204 & 4.7033 & .3158 \\
\hline .25 & .0847 & .3667 & .0157 & .58 & .2393 & 1.8530 & .1179 & .91 & .6555 & 4.8725 & .3233 \\
\hline .26 & .0923 & .3997 & .173 & .59 & .2151 & 1.9146 & .1227 & .92 & .0966 & 5.0603 & .3305 \\
\hline .27 & .0963 & .4259 & .0190 & .60 & .2511 & 1.9773 & .1276 & .93 & .7459 & 5.2726 & .3384 \\
\hline .28 & .1002 & .4571 & .0207 & .61 & .2572 & 2.0409 & .1326 & .94 & .8065 & 5.5183 & .3460 \\
\hline .29 & .1012 & .4893 & .0226 & .62 & .2635 & 2.1057 & .1376 & .95 & .5841 & 5.8118 & .3537 \\
\hline .30 & .1081 & .5225 & .0255 & .63 & .2699 & 2.1716 & .1428 & .96 & .9865 & 6.1787 & .3615 \\
\hline .31 & .1121 & .5568 & .0266 & .64 & .2765 & 2.2386 & .1481 & .97 & 1.1410 & 6.6692 & .3692 \\
\hline .32 & .1182 & .5921 & .0247 & .65 & .2933 & 2.3007 & .1531 & .98 & 1.3958 & 7.4063 & .3770 \\
\hline .33 & .1202 & .6281 & .0309 & .66 & .2602 & 2.3760 & .1589 & $\begin{array}{r}.99 \\
1.00\end{array}$ & 1.9700 & 8.8263 & $\begin{array}{l}.3848 \\
.3927\end{array}$ \\
\hline
\end{tabular}

Sumber: Anonim, 1987 
Tabel 2. Aliran Seragam pada Penampang Melingkar

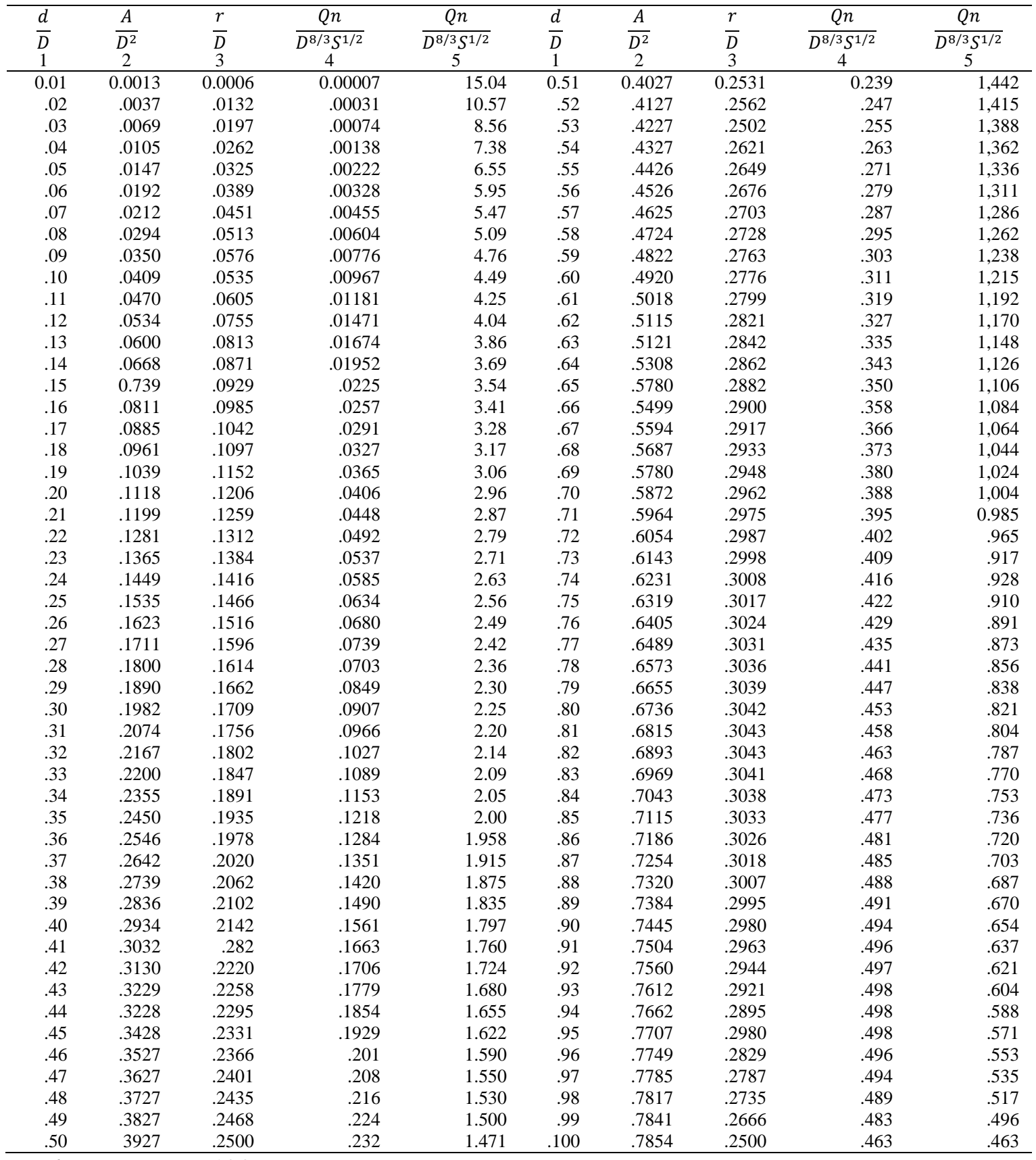

Sumber: Anonim, 1987

\subsection{Pembebanan}

Jenis beban dalam analisis kekuatan struktur terowongan pengelak adalah (Wicaksana, Suprijanto, \& Cahya, 2018):

1. Beban batuan arah vertikal (qbv) $\mathrm{q}_{\mathrm{bv}}=\gamma_{\mathrm{b}} \cdot \mathrm{H}_{\mathrm{p}}$
$\mathrm{H}_{\mathrm{p}}=0.3 \cdot\left(\mathrm{B}+\mathrm{H}_{\mathrm{t}}\right)$

$\gamma_{\mathrm{b}}=$ berat jenis batuan

$\mathrm{H}_{\mathrm{p}}=$ tinggi tekanan batuan

$\mathrm{B}$ = lebar batuan

$\mathrm{H}_{\mathrm{t}}=$ tinggi terowongan

2. Berat sendiri $(\mathrm{q})$ 


$$
\begin{aligned}
& q=\gamma_{c} \cdot t \\
& \gamma_{c}=\text { berat jenis beton } \\
& \mathrm{t}=\text { tebal terowongan } \\
& \mathrm{P}_{\mathrm{wv}}=\gamma_{\mathrm{w}} \cdot \mathrm{H}_{\mathrm{w}} \\
& \gamma_{\mathrm{w}}=\text { berat jenis air } \\
& \mathrm{H}_{\mathrm{w}}=\text { tinggi muka air di atas } \\
& \text { terowongan }
\end{aligned}
$$

4. Beban air arah horizontal $\left(\mathrm{P}_{\mathrm{wh}}\right)$

$$
\mathrm{P}_{\mathrm{wh}}=\gamma_{\mathrm{w}} \cdot \mathrm{H}_{\mathrm{w}}
$$

5. Beban air dalam terowongan $(\mathrm{P})$ $\mathrm{P}=\gamma_{\mathrm{w}} \cdot \mathrm{g} \cdot \mathrm{h}$

$\mathrm{g}$ = gaya gravitasi

$\mathrm{h}=$ tinggi muka air

6. Beban batuan arah horizontal untuk kondisi normal (qbh)

$\mathrm{q}_{\mathrm{bh}}=0.5 \cdot\left(\gamma_{\mathrm{b}} \cdot \mathrm{H}_{\mathrm{p}}\right)$

7. Beban batuan arah horizontal untuk kondisi terjadi gempa (qbhe)

$$
\begin{aligned}
& \text { qbhe }=0.5 \cdot\left(\gamma_{\mathrm{b}} \cdot \mathrm{H}_{\mathrm{p}}\right) \cdot \mathrm{K}_{\mathrm{h}} \ldots . \quad(8) \\
& \mathrm{K}_{\mathrm{h}}=\text { koefisien gempa yang } \\
& \text { dihitung berdasarkan } \\
& \text { Standar Nasional } \\
& \text { Indonesia (SNI) No: 1726- } \\
& 2019 \text { (Anonim, 2019b) }
\end{aligned}
$$

8. Beban uplift $\left(\mathrm{P}_{\mathrm{u}}\right)$

$$
\mathrm{P}_{\mathrm{u}}=\gamma_{\mathrm{w}} \cdot\left(\mathrm{H}_{\mathrm{w}}+\mathrm{H}_{\mathrm{t}}\right)
$$

Beban-beban tersebut kemudian dikombinasikan dalam empat kondisi yaitu kondisi normal setelah terowongan selesai dibangun, kondisi gempa setelah terowongan selesai dibangun, kondisi air pernuh saat terowongan beroperasi, kondisi gempa dan air penuh saat terowongan beroperasi (Rofikha et al., 2019).

1. Kombinasi pembebanan pada kondisi normal setelah terowongan selesai dibangun:
a. Berat sendiri
b. Beban batuan arah vertikal
c. Beban batuan arah horizontal untuk kondisi normal

2. Kombinasi pembebanan pada kondisi gempa setelah terowongan selesai dibangun:
a. Berat sendiri
b. Beban batuan arah vertikal
c. Beban batuan arah horizontal untuk kondisi terjadi gempa

3. Kombinasi pembebanan pada kondisi air pernuh saat terowongan beroperasi:
a. Berat sendiri
b. Beban batuan arah vertikal
c. Beban batuan arah horizontal untuk kondisi normal
d. Beban air arah vertikal
e. Beban air arah horizontal
f. Beban air dalam terowongan
g. Beban uplift 
4. Kombinasi pembebanan pada kondisi gempa dan air penuh saat terowongan beroperasi:
a. Berat sendiri
b. Beban batuan arah vertikal
c. Beban batuan arah horizontal untuk kondisi terjadi gempa
d. Beban air arah vertikal
e. Beban air arah horizontal
f. Beban air dalam terowongan
g. Beban uplift

\subsection{Gaya-Gaya Dalam}

Gaya-gaya dalam seperti momen, gaya normal dan gaya lintang ditentukan dengan menggunakan persamaan berikut ini (Philips \& Allen, 1986):

1. Perhitungan momen $(\mathrm{M})$ :

$$
\begin{aligned}
& \mathrm{M}=\mathrm{K}_{\mathrm{M}} \cdot \mathrm{W} \cdot \mathrm{r}^{2} \ldots \ldots \ldots \ldots \ldots \ldots \ldots \\
& \mathrm{K}_{\mathrm{M}}=\text { koefisien momen } \\
& \mathrm{W}=\text { beban yang bekerja } \\
& \mathrm{r}=\text { jari-jari terowongan }
\end{aligned}
$$

2. Perhitungan gaya normal $(\mathrm{N})$ :

$$
\mathrm{N}=\mathrm{K}_{\mathrm{N}} \cdot \mathrm{W} \cdot \mathrm{r}
$$

$\mathrm{K}_{\mathrm{N}}=$ koefisien gaya normal

3. Perhitungan gaya lintang (D):

$\mathrm{D}=\mathrm{K}_{\mathrm{D}} \cdot \mathrm{W} \cdot \mathrm{r}$

$\mathrm{K}_{\mathrm{D}}=$ koefisien gaya lintang

\subsection{Penulangan}

Penulangan diperlukan pada beton, karena beton lemah terhadap gaya tarik. Analisis penulangan beton mengacu terhadap peraturan SNI No: 2847:2013 tentang persyaratan beton struktural untuk bangunan gedung (Anonim, 2013).

\subsection{Stabilitas Bangunan}

Syarat sebuah bangunan terowongan pengelak bisa disebut stabil jika memenuhi kriteria berikut (Wicaksana et al., 2018):

$$
\begin{array}{r}
\mathrm{q}_{\text {vertikal total }}<\mathrm{q}_{\mathrm{u}} \ldots \ldots \ldots \ldots \ldots \ldots \ldots \ldots \\
\mathrm{q}_{\text {vertikal total }}=\mathrm{q}_{\mathrm{bv}}+\mathrm{q}+\mathrm{P}_{\mathrm{wv}}+\mathrm{P} \ldots \\
\mathrm{q}_{\mathrm{u}}=\mathrm{q}_{\mathrm{bv}}+\mathrm{q}+\mathrm{P}_{\mathrm{wv}}+\mathrm{P}_{\mathrm{wh}}+\mathrm{P}+ \\
\mathrm{q}_{\mathrm{bh}}+\mathrm{q}_{\mathrm{bhe}}+\mathrm{P}_{\mathrm{u}}
\end{array}
$$

\section{METODE PENELITIAN}

\subsection{Lokasi Bendungan}

Peta lokasi pembangunan

Bendungan Sidan dapat dilihat pada Gambar 1.

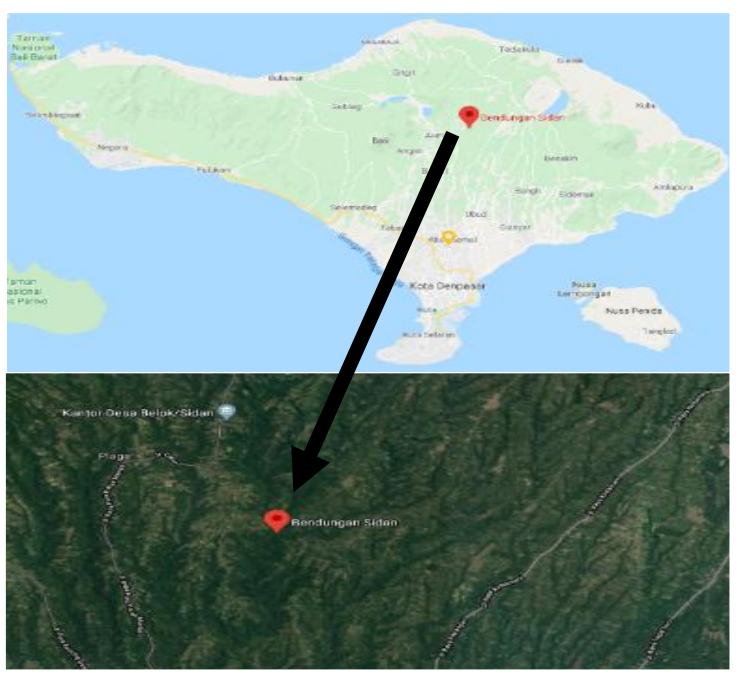

Gambar 1. Peta Lokasi Bendungan Sidan (Sumber: Google Maps)

\subsection{Alur Perencanaan}

Alur perencanaan arternatif dimensi terowongan pengelak seperti Gambar 2. 


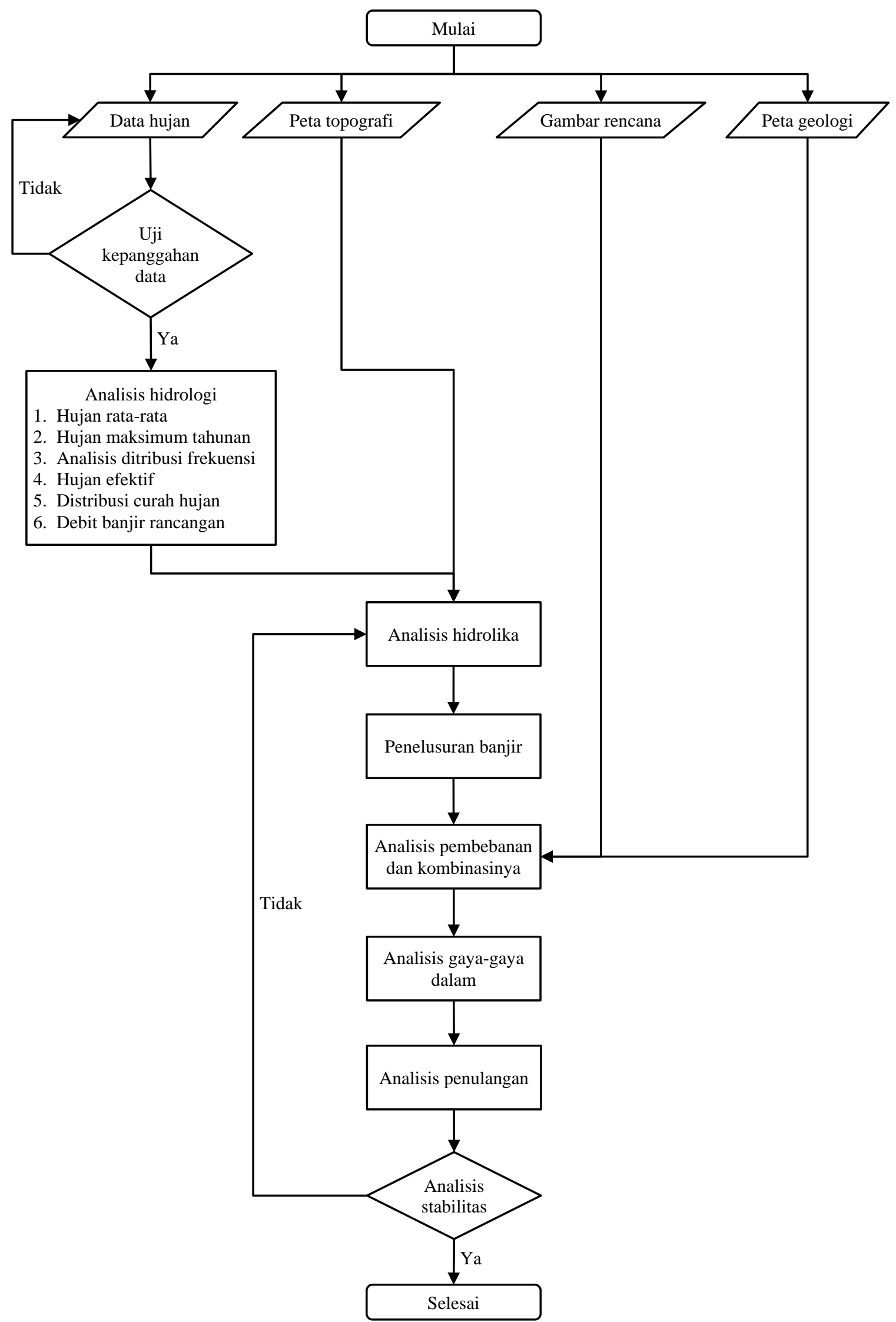

Gambar 2. Alur Perencanaan Arternatif Dimensi Terowongan Pengelak 


\subsection{Pengumpulan Data}

Data yang dipergunakan dalam studi ini merupakan data sekunder yang diperoleh dari berbagai instansi. Data hujan periode tahun 2009 sampai 2018 diperoleh dari Balai Wilayah Sungai BaliPenida. Peta topografi yang menunjukan posisi stasiun hujan, panjang sungai, dan luas daerah tangkapan juga disediakan oleh Balai Wilayah Sungai Bali-Penida. Gambar rencana yang memuat informasi tentang elevasi inlet dan outlet terowongan dan panjang terowongan diperoleh dari kontraktor pelaksana PT. Brantas Abipraya (Persero) - PT. Universal Suryaprima. Peta geologi yang memuat jenis batuan pada lokasi bendungan diperoleh berdasarkan peta geologi wilayah Provinsi Bali.

\subsection{Hidrolika Terowongan}

Perhitungan hidrolika terowongan menggunakan dua kondisi yaitu aliran bebas dan tertekan (Wicaksana et al., 2018):

1. Aliran bebas $(\mathrm{h}<1.2 \mathrm{~d})$ :

$\mathrm{V}=1 / \mathrm{n} \cdot \mathrm{R}^{2 / 3} \cdot \mathrm{S}^{1 / 2}$

$\mathrm{Q}=\mathrm{A} \cdot \mathrm{V}$

dengan:

$\mathrm{V}=$ kecepatan aliran

$\mathrm{R}=$ jari - jari hidrolis

$\mathrm{S}=$ kemiringan saluran

$\mathrm{n}=$ koefisien kekasaran

Manning (0.014)
$\mathrm{Q}=$ debit air

$\mathrm{A}=$ luas penampang

2. Aliran tertekan $(\mathrm{h}>1.5 \mathrm{~d})$

$$
\begin{aligned}
& \mathrm{V}=\sqrt{\frac{2 \mathrm{~g} \cdot(\mathrm{H}-\mathrm{D}+\mathrm{Z})}{\left(1+\mathrm{C}_{\mathrm{i}}+\mathrm{C}_{\mathrm{f}}\right)}} \\
& \mathrm{C}_{\mathrm{f}}=\frac{\mathrm{n}^{2} \cdot \mathrm{L}}{\mathrm{R}^{4 / 3}}
\end{aligned}
$$

$\mathrm{D}$ = diameter terowongan

$\mathrm{Z}$ = perbedaan elevasi mulut terowongan dengan bagian akhir terowongan

$\mathrm{C}_{\mathrm{i}}=$ koefisien kehilangan energi pada inlet $(0.5)$

$\mathrm{C}_{\mathrm{f}}=$ koefisien gesekan

\section{HASIL DAN PEMBAHASAN}

\subsection{Analisis Hidrologi}

Berdasarkan hasil analisis curah hujan dan perhitungan hidrograf satuan sintetik Nakayasu maka diperoleh puncak debit banjir rancangan untuk periode kala ulang 25 tahun sebesar $265.54 \mathrm{~m}^{3} / \mathrm{dt}$ yang terjadi pada waktu 2 jam. Gambar 3 menunjukan debit banjir rancangan untuk setiap periode waktu pada kala ulang 25 tahun. Debit banjir rancangan ini yang nantinya akan digunakan sebagai debit input $\left(\mathrm{Q}_{\text {inflow }}\right)$ pada saat analisis penelusuran banjir pada terowongan pengelak. 


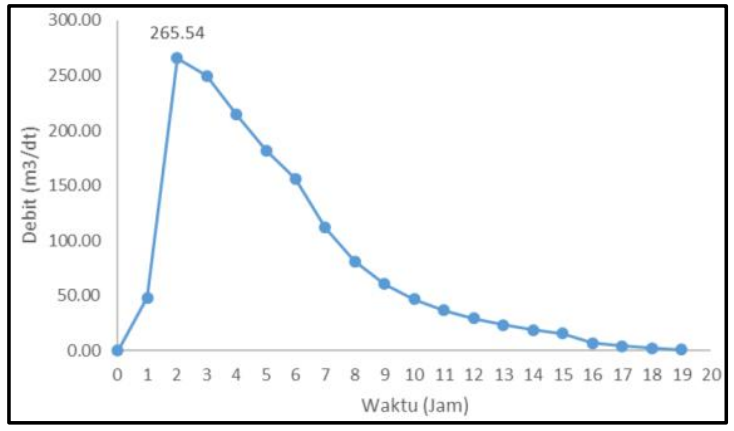

Gambar 3. Debit Banjir Rancangan Periode Ulang 25 Tahun

\subsection{Analisis Hidrolika}

Analisis hidrolika aliran dibagi menjadi dua kondisi yaitu aliran bebas dan tertekan. Diameter terowongan direncankan 5 meter.

\subsubsection{Aliran bebas}

Berdasarkan analisis dengan menggunakan Persamaan 16 dan 17 serta Tabel 1 dan 2, maka hasil kapasitas debit untuk aliran bebas pada terowongan dapat dilihat pada Tabel 3 dan 4.

Tabel 3. Analisis R, V, dan Q untuk Aliran Bebas

\begin{tabular}{cccccccc}
\hline $\begin{array}{c}\mathrm{h} \\
(\mathrm{m})\end{array}$ & $\mathrm{h} / \mathrm{D}$ & $\mathrm{A} / \mathrm{D}^{2}$ & $\mathrm{~A}$ & $\mathrm{R} / \mathrm{D}$ & $\mathrm{R}^{2 / 3}$ & $\mathrm{~V}$ & $\mathrm{Q}$ \\
\hline 1 & 0.2 & 0.11 & 2.8 & 0.1206 & 0.7137 & 9.94 & 27.77 \\
2 & 0.4 & 0.29 & 7.34 & 0.2142 & 1.0468 & 14.57 & 106.88 \\
3 & 0.6 & 0.49 & 12.3 & 0.2776 & 1.2443 & 17.32 & 213.04 \\
4 & 0.8 & 0.67 & 16.84 & 0.3042 & 1.3226 & 18.41 & 310.03 \\
5 & 1 & 0.79 & 19.64 & 0.25 & 1.1604 & 16.15 & 317.16 \\
\hline
\end{tabular}

Tabel 4. Analisis Elevasi Muka Air dan Q untuk Aliran Bebas

\begin{tabular}{|c|c|c|c|c|c|}
\hline $\begin{array}{l}\mathrm{H} \\
(\mathrm{m}) \\
\end{array}$ & $\begin{array}{c}\mathrm{V} \\
(\mathrm{m} / \mathrm{dt}) \\
\end{array}$ & $\begin{array}{l}\mathrm{V} 2 \\
2 \mathrm{~g} \\
\end{array}$ & $C i \frac{V^{2}}{2 g}$ & $\begin{array}{c}\text { Elevasi } \\
\text { Muka Air } \\
(\mathrm{m})\end{array}$ & $\begin{array}{c}\mathrm{Q} \\
\left(\mathrm{m}^{3} / \mathrm{dt}\right)\end{array}$ \\
\hline 1 & 9.94 & 5.03 & 2.52 & 779.55 & 27.77 \\
\hline 2 & 14.57 & 10.82 & 5.41 & 789.23 & 106.88 \\
\hline 3 & 17.32 & 15.29 & 7.65 & 796.94 & 213.04 \\
\hline 4 & 18.41 & 17.28 & 8.64 & 800.91 & 310.03 \\
\hline 5 & 16.15 & 13.30 & 6.65 & 795.95 & 317.16 \\
\hline
\end{tabular}

\subsubsection{Aliran tertekan}

Berdasarkan analisis dengan menggunakan Persamaan 18 dan 19 serta Tabel 1 dan 2, maka hasil kapasitas debit untuk aliran tertekan pada terowongan terlihat pada Tabel 5 .

Tabel 5. Analisis Elevasi Muka Air dan Q untuk Aliran Tertekan

\begin{tabular}{|c|c|c|}
\hline $\begin{array}{c}\text { Elevasi } \\
\text { (m) }\end{array}$ & $\begin{array}{c}\mathrm{H} \\
(\mathrm{m})\end{array}$ & $\begin{array}{c}\mathrm{Q} \\
\left(m^{3} / d t\right)\end{array}$ \\
\hline 776.00 & 5.00 & 69.24 \\
\hline 777.00 & 6.00 & 97.90 \\
\hline 778.00 & 7.00 & 119.90 \\
\hline 779.00 & 8.00 & B8.44 \\
\hline 780.00 & 9.00 & 154.78 \\
\hline 781.00 & 1000 & 169.55 \\
\hline 782.00 & 1100 & 183.14 \\
\hline 783.00 & 1200 & 195.78 \\
\hline 784.00 & 1300 & 207.66 \\
\hline 785.00 & 1400 & 218.89 \\
\hline 786.00 & 1500 & 229.57 \\
\hline 787.00 & 1600 & 239.78 \\
\hline 788.00 & 1700 & 249.57 \\
\hline 789.00 & 1800 & 258.99 \\
\hline 790.00 & 1900 & 268.08 \\
\hline 791.00 & 2000 & 276.87 \\
\hline 792.00 & 2100 & 285.39 \\
\hline 793.00 & 2200 & 293.66 \\
\hline 794.00 & 2300 & 301.71 \\
\hline 795.00 & 2400 & 309.55 \\
\hline 796.00 & 2500 & 317.19 \\
\hline 797.00 & 2600 & 324.65 \\
\hline 798.00 & 2700 & 331.95 \\
\hline 799.00 & 2800 & 339.09 \\
\hline 800.00 & 2900 & 346.08 \\
\hline 801.00 & 3000 & 352.94 \\
\hline 802.00 & 3100 & 359.66 \\
\hline 803.00 & 3200 & 366.26 \\
\hline 804.00 & 3300 & 372.74 \\
\hline 805.00 & 34.00 & 379.11 \\
\hline
\end{tabular}

\subsubsection{Cofferdam}

Analisis cofferdam dihitung dengan: 


$$
\begin{aligned}
& \frac{\mathrm{S}_{1}}{\Delta \mathrm{t}}-\frac{\mathrm{O}_{1}}{2}=\psi \\
& \frac{\mathrm{S}_{2}}{\Delta \mathrm{t}}+\frac{\mathrm{O}_{2}}{2}=\varphi
\end{aligned}
$$

Maka:

$\frac{\mathrm{I}_{1}+\mathrm{I}_{2}}{2}+\psi=\varphi$

Tabel 6 menyajikan perhitungan penelusuran banjir untuk periode 25 tahun $\left(\mathrm{Q}_{25}\right)$.

Tabel 6. Analisis Debit Masuk $\left(Q_{\text {inflow }}\right)$ dan

\begin{tabular}{|c|c|c|c|c|c|c|}
\hline $\begin{array}{c}\mathrm{T} \\
(\mathrm{Jam})\end{array}$ & $\begin{array}{l}\mathrm{Q}_{\text {inflow }} \\
\mathrm{m}^{3} / \mathrm{dt}\end{array}$ & $\frac{\mathrm{Q}_{1}+\mathrm{Q}_{2}}{2}$ & $\psi$ & $\varphi$ & $\begin{array}{c}\mathrm{H} \\
(\mathrm{m})\end{array}$ & $\begin{array}{l}\mathrm{Q}_{\text {oufflow }} \\
\mathrm{m}^{3} / \mathrm{dt}\end{array}$ \\
\hline 0 & 0.00 & 0.00 & 0.000 & 0.000 & 0.00 & 0.000 \\
\hline 1 & 47.97 & 23.98 & -4.918 & 23.983 & 2.14 & 28.901 \\
\hline 2 & 265.54 & 156.75 & -24.559 & 151.837 & 10.51 & 176.436 \\
\hline 3 & 249.52 & 257.53 & -5.862 & 232.931 & 15.90 & 238.793 \\
\hline 4 & 214.35 & 231.93 & -8.166 & 226.072 & 15.46 & 234.238 \\
\hline 5 & 181.86 & 198.11 & -18.499 & 189.94 & 13.07 & 208.44 \\
\hline 6 & 156.29 & 169.07 & -24.710 & 150.575 & 10.42 & 175.285 \\
\hline 7 & 112.03 & 134.16 & -24.035 & 109.448 & 7.73 & 133.483 \\
\hline 8 & 81.29 & 96.66 & -14.79 & 72.621 & 5.63 & 87.41 \\
\hline 9 & 60.33 & 70.81 & -8.967 & 56.017 & 4.74 & 64.984 \\
\hline 10 & 46.73 & 53.53 & -7.156 & 44.562 & 3.89 & 51.717 \\
\hline 11 & 36.79 & 41.76 & -6.625 & 34.605 & 3.02 & 41.23 \\
\hline 12 & 29.26 & 33.03 & -5.312 & 26.401 & 2.34 & 31.713 \\
\hline 13 & 23.49 & 26.38 & -4.452 & 21.064 & 1.89 & 25.516 \\
\hline 14 & 19.04 & 21.27 & -3.792 & 16.814 & 1.51 & 20.606 \\
\hline 15 & 15.47 & 17.26 & -3.272 & 13.463 & 1.21 & 16.735 \\
\hline
\end{tabular}
Debit Keluar ( $\left.\mathbf{Q}_{\text {outflow }}\right)$

Dari perhitungan flood routing didapat muka air naik sampai elevasi: $771.00+15.46=786.46$, jika tinggi jagaan yang diperlukan untuk keamanan cofferdam diambil $=3.00 \mathrm{~m}$ maka elevasi puncak cofferdam menjadi $=786.46+3.00$ $=789.46$.

Tinggi cofferdam $=$ Tinggi muka air maksimum + tinggi jagaan
Tinggi cofferdam $=15.46+3=$ $18.46 \mathrm{~m} \sim 18.50 \mathrm{~m}$

\subsection{Analisis Pembebanan}

Pembebanan pada terowongan dihitung dengan menggunakan Persamaan 1 sampai dengan Persamaan 9. Tabel 7 memperlihatkan hasil perhitungan pembebanan pada terowongan.

Tabel 7. Pembebanan pada Terowongan

\begin{tabular}{ccc}
\hline Jenis Beban & Satuan & Nilai Beban \\
\hline $\mathrm{q}_{\mathrm{bv}}$ & ton $/ \mathrm{m}^{2}$ & 6.24 \\
$\mathrm{q}$ & ton $/ \mathrm{m}^{2}$ & 1.2 \\
$\mathrm{P}_{\mathrm{wv}}$ & ton $/ \mathrm{m}^{2}$ & 17.5 \\
$\mathrm{P}_{\mathrm{wh}}$ & ton $/ \mathrm{m}^{2}$ & 17.5 \\
$\mathrm{P}$ & ton $/ \mathrm{m}^{2}$ & 49.05 \\
$\mathrm{q}_{\mathrm{bh}}$ & ton $/ \mathrm{m}^{2}$ & 3.12 \\
$\mathrm{q}_{\mathrm{bhe}}$ & ton $/ \mathrm{m}^{2}$ & 1.6 \\
$\mathrm{P}_{\mathrm{u}}$ & ton $/ \mathrm{m}^{2}$ & 22.5 \\
\hline
\end{tabular}

Nilai beban pada Tabel 7 kemudian dikombinasikan dalam empat kondisi yaitu:

1. Kombinasi 1 yaitu kondisi normal setelah terowongan selesai dibangun.

2. Kombinasi 2 yaitu kondisi gempa setelah terowongan selesai dibangun.

3. Kombinasi 3 yaitu kondisi air pernuh saat terowongan beroperasi.

4. Kombinasi 4 yaitu kondisi gempa dan air penuh saat terowongan beroperasi 
Hasil kombinasi pembebanan dapat dilihat pada Tabel 8 di bawah ini:

Tabel 8. Kombinasi Pembebanan

\begin{tabular}{ccc}
\hline Kondisi & Satuan & Nilai Beban \\
\hline Kombinasi 1 & ton $/ \mathrm{m}^{2}$ & 10.56 \\
Kombinasi 2 & ton $/ \mathrm{m}^{2}$ & 9.04 \\
Kombinasi 3 & ton $/ \mathrm{m}^{2}$ & 117.11 \\
Kombinasi 4 & ton $/ \mathrm{m}^{2}$ & 115.60 \\
\hline
\end{tabular}

\subsection{Analisis Gaya-Gaya Dalam}

Gaya-gaya dalam yang terdiri dari momen, gaya lintang, dan gaya normal dihitung dengan menggunakan Persamaan 10 sampai dengan Persamaan 12. Hasil perhitungan momen, gaya lintang, dan gaya normal maksimum untuk masingmasing kondisi terlihat pada Tebel 9.

Tabel 9. Nilai Gaya-Gaya Dalam Maksimum

\begin{tabular}{cccc}
\hline Kondisi & $\begin{array}{c}\mathrm{M} \\
\text { (ton.m) }\end{array}$ & $\mathrm{D}$ (ton) & $\mathrm{N}$ (ton) \\
\hline Kombinasi 1 & 19.272 & 15.391 & 53.222 \\
Kombinasi 2 & 16.498 & 13.176 & 45.562 \\
Kombinasi 3 & 213.726 & 170.688 & 590.234 \\
Kombinasi 4 & 210.970 & 168.487 & 582.624 \\
\hline
\end{tabular}

Berdasarkan Tabel 9 dapat diketahui bahwa gaya-gaya dalam terbesar terjadi pada kombinasi ketiga yaitu pada kondisi air pernuh saat terowongan beroperasi. Nilai momen, gaya lintang, dan gaya normal maksimum berturut-turut 213.726 ton.m, 170.688 ton, dan 590.234 ton. Nilai gaya-gaya dalam maksimum ini akan digunakan dalam analisis penulangan terowongan.

\subsection{Analisis Penulangan}

\subsubsection{Tulangan utama}

1. Jarak efektif tulangan:

Direncanakan dimater tulangan

(D) adalah $25 \mathrm{~mm}$.

$$
\begin{aligned}
\mathrm{d}= & \text { tebal beton }- \text { beton } \\
& \text { decking }-0.5 \mathrm{D} \\
= & 500-75-(0.5 \times 25) \\
= & 412.5 \mathrm{~mm}
\end{aligned}
$$

2. Momen ultimate:

$$
\begin{aligned}
\mathrm{M}_{\mathrm{u}} & =213.726 \text { Ton.m } \\
& =2091523.09 \text { N.mm }
\end{aligned}
$$

3. Momen nominal:

$$
\begin{aligned}
\mathrm{M}_{\mathrm{n}} & =\frac{\mathrm{M}_{\mathrm{u}}}{\varphi}=\frac{2091523.09}{0.8} \\
& =2614403.9 \mathrm{~N} . \mathrm{mm}
\end{aligned}
$$

4. Rasio penulangan:

$$
\begin{aligned}
\mathrm{b} & =1000 \mathrm{~mm} \\
\mathrm{R}_{\mathrm{n}} & =\frac{\mathrm{M}_{\mathrm{n}}}{\mathrm{bxd}^{2}}=\frac{2614403.9}{1000 \times 412.5^{2}} \\
& =0.015 \\
\rho & =\frac{1}{\mathrm{~m}} \times\left[1-\sqrt{1-\frac{2 \times \mathrm{m} \times \mathrm{R}_{\mathrm{n}}}{\mathrm{f}_{\mathrm{y}}}}\right] \\
& =\frac{1}{13.44}\left[1-\sqrt{1-\frac{2 \times 13.44 \times 0.015}{400}}\right] \\
& =3.75 \times 10^{-5} \\
\rho_{\min } & =3.5 \times 10^{-3} \\
\rho & <\rho_{\min }
\end{aligned}
$$

5. Luas tulangan:

$$
\begin{aligned}
A_{\text {s }} & =\rho_{\min } \times \mathrm{b} \times \mathrm{d} \\
& =0.0035 \times 1000 \times 412.5 \\
& =1443.75 \mathrm{~mm}^{2}
\end{aligned}
$$

6. Jumlah tulangan:

$\mathrm{n}=\frac{A_{S}}{0.25 \times 3.14 \times 25^{2}}=\frac{1443.75}{490.62}$ 


$$
=2.94 \sim 3=3 \text { buah }
$$

Maka diambil tulangan sebanyak 3 buah tulangan per 1 meter.

7. Jarak tulangan

$$
\text { Jarak }=\frac{1000}{\mathrm{n}-1}=\frac{1000}{3-1}=500 \mathrm{~mm}
$$

Maka dipakai tulangan 3D25-500 untuk penulangan utama terowongan pengelak.

\subsubsection{Tulangan pembagi:}

Tulangan pembagi diletakan tegak lurus terhadap tulangan utama sebagai antisipasi terhadap kemungkinan terjadinya susut dan pemuaian akibat suhu. Perhitungan tulangan pembagi adalah sebagai berikut:

$$
\begin{aligned}
\text { As } & =0.0018 \cdot \mathrm{b} \cdot \mathrm{h} \\
& =0.0018 \cdot 1000 \cdot 500 \\
& =900 \mathrm{~mm}^{2}
\end{aligned}
$$

Tulangan pembagi direncanakan menggunakan tulangan dengan diameter $25 \mathrm{~mm}$. Jarak antar tulangan dihitung sebagai berikut:

$$
\begin{aligned}
\text { Jarak } & =\frac{0.25 \times 3.14 \times 25^{2} \times 1000}{900} \\
& =545.14 \sim 500 \mathrm{~mm}
\end{aligned}
$$

Tulangan pembagi yang digunakan pada terowongan pengelak adalah D25500 .

\subsection{Analisis Stabilitas}

Stabilitas dihitung dengan menggunakan Persamaan 13 sampai dengan Persamaan 15.

$$
\begin{aligned}
& \mathrm{q}_{\text {vertikal total }}=73.99 \mathrm{ton} / \mathrm{m}^{2} \\
& \mathrm{qu}_{\mathrm{u}}=118.71 \mathrm{ton} / \mathrm{m}^{2}
\end{aligned}
$$

Nilai qvertikal total lebih kecil dari $\mathrm{qu}_{\mathrm{u}}$ maka dapat disimpulkan bahwa terowongan stabil.

\section{SIMPULAN DAN SARAN}

\subsection{Simpulan}

Kesimpulan yang dapat ditarik berdasarkan hasil analisis adalah sebagai berikut:

1. Terowongan pengelak direncanakan berbentuk lingkaran dengan diameter $5 \mathrm{~m}$, dengan debit rancangan kala ulang 25 tahun sebesar 265.54 $\mathrm{m}^{3} / \mathrm{dt}$.

2. Tebal dinding terowongan direncanakan setebal $0.5 \mathrm{~m}$ dengan bahan terbuat dari beton bertulang, dimana pada tulangan utama menggunakan 3D25-500 dan pada tulangan bagi mengunakan D25-500.

\subsection{Saran}

Analisis dimensi pada studi ini hanya terbatas pada satu diameter dan tebal dinding terowongan saja. Uji coba 
menggunaka diameter dan tebal dinding yang berbeda-beda sangat diperlukan untuk mendapatkan diameter dan tebal dinding terowongan yang paling efektif.

\section{DAFTAR PUSTAKA}

Anonim. (1987). Design of Small Dams. Washington DC: Bureau of Reclamation.

Anonim. (2013). SNI 2847:2013 tentang Persyaratan Beton Struktural Untuk Bangunan Gedung. Jakarta: Badan Standardisasi Nasional.

Anonim. (2019a). Belajar Pengelolaan Sumber Daya Air Ke Bali. Retrieved from e-Parlemen DPRD Daerah Istimewa Yogyakarta website: https://www.dprd-diy.go.id/belajarpengelolaan-sumber-daya-air-kebali/

Anonim. (2019b). SNI 03-1726-2019 tentang Tata Cara Perencanaan Ketahanan Gempa untuk Struktur Bangunan Gedung dan Non Gedung. Jakarta: Badan Standardisasi Nasional.

Aryastana, P., Rahadiani, A. A. S. D., \& Adnyana, W. S. (2019). Analisis Pemenuhan Kebutuhan Air Bersih Masyarakat Dusun Kiadan, Desa Pelaga, Kabupaten Badung. Konferensi Nasional Teknik Sipil (KoNTekS) - 13, 501-508.

Biemans, H., Haddeland, I., Kabat, P., Ludwig, F., Hutjes, R. W. A., Heinke, J., ... Gerten, D. (2011). Impact of reservoirs on river discharge and irrigation water supply during the 20th century. Water Resources Research, 47(3). https://doi.org/10.1029/2009WR008 929.
Darmayasa, I. K. A., Aryastana, P., \& Rahadiani, A. A. S. D. (2018). Analisis Kebutuhan Air Bersih Masyarakat Kecamatan Petang. PADURAKSA, 7(1), 41-52.

Loebis, J. (1987). Banjir rencana untuk bangunan air. Jakarta: Badan Penerbit Pekerjaan Umum.

Philips, H. B., \& Allen, I. E. (1986). Beegs Deformeter Stress Analysis of Single Barrel Conduits. Colorado: United States Bureau of Reclamation.

Rofikha, A. A., Marsudi, S., \& Cahya, E. N. (2019). Analisis Struktur Terowongan Pengelak pada Bendungan Kuala Kabupaten Toba Samosir Provinsi Sumatra Utara. Jurnal Teknik Pengairan, 10(1), 2838.

Simatupang, S. A., Tanan, B., \& Lukman, M. (2020). Tinjauan Perencanaan Terowongan Pengelak Bendungan Karalloe di Kabupaten Gowa. Paulus Civil Engineering Journal, 2(1), 6369.

Soemarto, C. D. (1987). Hidrologi Teknik. Surabaya: Usaha Nasional.

Sosrodarsono, S., \& Takeda, K. (1977). Hidrologi untuk Pengairan. Jakarta: Pradnya Paramita.

Triatmodjo, B. (2008). Hidrologi Terapan. Yogyakarta: Beta Offset.

Wicaksana, C. Y., Suprijanto, H., \& Cahya, E. N. (2018). Studi Perencanaan Terowongan Pengelak Bendungan Lubuk Ambacang Kecamatan Hulu Kuantan Kabupaten Kuantan Singingi Provinsi Riau. Jurnal Mahasiswa Jurusan Teknik Pengairan, 2(1). 